\title{
Analysis Investor Index Indonesia with Capital Asset Pricing Model (CAPM)
}

\author{
P. Erry Sigit Pramono ${ }^{1}$, Dudi Rudianto ${ }^{2}$, Fernando Siboro ${ }^{3}$, Muhamad Puad Abdul Baqi ${ }^{4}$, \\ Dwi Julianingsih ${ }^{5}$
}

Bakrie University, Indonesia ${ }^{1,2}$

University of Raharja, Indonesia ${ }^{3,4,5}$

e-mail: admisi@bakrie.ac.id ${ }^{1}$,dudi.rudianto@bakrie.ac.id ${ }^{2}$, fernando.siboro@raharia.info ${ }^{3}$, puad@raharja.info ${ }^{4}$, dwi.julianingsih@raharja.info ${ }^{5}$

Pramono, . E. S. ., Rudianto, D. ., Siboro, F. ., Abdul Baqi , M. P. ., \& Julianingsih, D. (2022). Analysis Investor Index Indonesia with Capital Asset Pricing Model (CAPM). Aptisi Transactions on Technopreneurship (ATT), 4(1), 38-49.

DOI: https://doi.org/10.34306/att.v4i1.218

\section{Abstract}

This study aimed to compare composition of the optimal portfolio of stocks, the proportion of funds in each of these stocks and calculate risk and return portfolio from Investor33 (INV33) Index and Jakarta Islamic Index (JII) in the research period January 2016-December 2018. The method used in this research is a quantitative descriptive method. Sample in this study using purposive sampling were 24 stocks from the INV33 Index and 17 stocks from JII Index.

The results of the study were as follows : (1) The optimal portfolio of stocks by using capital asset pricing model from INV33 Index are CPIN (Charoen Pokphand Indonesia Tbk), ITMG (Indo Tambangraya Megah Tbk), BBCA (Bank Central Asia Tbk), UNTR (United Tractor Tbk), (TLKM) Telekomunikasi Indonesia (Persero) Tbk, ICBP (Indofood CBP Sukses Makmur Tbk), BBTN (Bank Tabungan Negara Persero Tbk and from JII Index are ADRO (Adaro Energy Tbk), ICBP (Indofood CBP Sukses Makmur Tbk), INCO (Vale Indonesia Tbk), INDF (Indofood Sukses Makmur Tbk), TLKM (Telekomunikasi Indonesia Persero Tbk), UNTR (United Tractor Tbk). (2) The composition of the proportion of funds in optimal portfolio formed by INV33 Index are BBCA (46,49\%), CPIN (20,11\%), ICBP (12,78\%), ITMG (8,59\%), UNTR (6,95\%), TLKM (4,11\%) and BBTN (0,97\%) and from JII Index are ICBP $(34,96 \%)$, ADRO $(19,47 \%), \operatorname{UNTR}(16,26 \%), \operatorname{INCO}(10,88 \%), \operatorname{TLKM}(10,43 \%)$ and INDF (8,00\%). (3)

The optimal portfolio of stocks return from INV33 Index was greater than stock portfolio return from JII Index and the optimal portfolio of stocks risk from INV33 Index was lower than stock portfolio risk from JII Index.

Keywords: Stock Optimal Portfolio, Capital Asset Pricing Model, INV33 Index and JII Index 


\section{Introduction}

The stock portfolio aims to select the most efficient combination of stocks, namely those that provide the greatest expected return in the future with a certain level of risk. In principle, a stock portfolio in addition to maximizing returns also avoids risk because not all stock investments can increase their returns.

The essence of the formation of an efficient and optimal portfolio is to reduce risk by diversifying shares, namely allocating a number of investor funds to various investment alternatives that are negatively correlated with the aim that the funds issued by investors can generate optimal returns. the definition of a portfolio as a collection of many assets so that exposure to certain assets is limited while Elton et. al. (2014) stated that a portfolio is a collection of several investment alternatives. Because investment is a trade-off between return and investment risk (Reilly and Brown, 2012), the purpose of portfolio formation is to maximize return and minimize risk. The question that arises is which company shares should be included in the portfolio? Investors must have knowledge in order to be able to determine which company shares will be selected in their portfolio and how much funds will be allocated in each of the selected shares. There are still many investors who have difficulty choosing stocks to include in their portfolios and the use of funds for each of the selected stocks. So that portfolio analysis can help investors make decisions to choose the optimal stock.

This study uses the CAPM model because CAPM is a model that can describe or predict the reality in a complex market and is a balance model that describes the relationship between risk and return in a simpler way because it only uses one variable (also known as the Beta variable) to describe risk. Because the CAPM can describe the relationship between risk and return in a simpler way, each investor can do portfolio analysis himself to find out which portfolio is profitable and how to optimize the returns from a portfolio combination by considering the level of risk of the existing portfolio. CAPM can help investors in a portfolio by calculating the risk that cannot be diversified and comparing it with the predicted rate of return (return). Based on the CAPM, the level of risk and the rate of return is stated to have a positive and linear relationship.

Research on the formation of an optimal portfolio using the Capital Asset Pricing Model has been carried out previously by Sipa (2018) with the title "Analysis of Optimal Stock Portfolio Formation Using the Capital Asset Pricing Model (Empirical Study on Stocks Included in the LQ 45 Index on the Indonesia Stock Exchange)" and Sevanya and Abriandi (2016) with the title "Optimal Portfolio Formation by Using the Capital Asset Pricing Model on the Stocks Incorporated in the LQ 45 Index on the Indonesia Stock Exchange for the 2011-2015 Period". The research period used in this study is the 2016-2018 period due to the use of the latest data and the time period used for moderate investors is 3 years.

This study aims to compare the composition of the optimal stock portfolio along with the proportion of funds in each stock based on the results of the optimal portfolio formation on the stocks included in the INV33 and JII indexes using the CAPM and to compare returns and risks for each stock included in the index. INV33 and JII. Based on the problems above, the researcher is interested in conducting research with the title "Comparative Analysis of Optimal Portfolio Formation with the Capital Asset Pricing Model (CAPM) method on stocks in the Investor33 Index and Jakarta Islamic Index (JII) 2016-201.

\section{Method}

Some of the previous studies used as a reference in writing this research include the following: 


\begin{tabular}{|c|c|c|c|}
\hline No. & Researcher & Title & Result \\
\hline 1 & $\begin{array}{l}\text { Sipa, Alfinia Ahmad } \\
(2018)\end{array}$ & $\begin{array}{l}\text { Analysis of Optimal Stock } \\
\text { Portfolio Formation Using } \\
\text { Capital Asset Pricing Model } \\
\text { (Empirical Study on Stocks } \\
\text { Included in the LQ } 45 \text { Index } \\
\text { on the Indonesia Stock } \\
\text { Exchange) }\end{array}$ & $\begin{array}{l}\text { The results showed the selection } \\
\text { of } 6 \text { stocks that make up the } \\
\text { optimal portfolio of } \\
38 \text { research samples. The } \\
\text { composition of the proportion of } \\
\text { funds formed using the JCI as a } \\
\text { proxy for market returns is } \\
53.76 \% \text { allocated to WSKT } \\
\text { shares, } 11.83 \% \text { allocated to AKRA } \\
\text { shares, } 14.55 \% \text { allocated to BBTN } \\
\text { shares, } 10.46 \% \text { allocated to PTPP } \\
\text { shares, } 5.97 \% \text { was allocated to } \\
\text { TLKM shares, and } 3.43 \% \text { was } \\
\text { allocated to ICBP shares. The } \\
\text { composition of the proportion of } \\
\text { funds formed using the LQ } 45 \\
\text { index as a proxy for market return } \\
\text { is } 51.16 \% \text { allocated to WSKT } \\
\text { shares, } 11.44 \% \text { allocated to AKRA } \\
\text { shares, } 14.98 \% \text { allocated to BBTN } \\
\text { shares, } 10.76 \% \text { allocated to PTPP } \\
\text { shares }, 7.73 \% \text { allocated to TLKM } \\
\text { shares, and } 3.93 \% \\
\text { allocated to ICBP shares }\end{array}$ \\
\hline 2 & $\begin{array}{l}\text { Sevanya,Adelina D.P } \\
\text { dan Abriandi, (2017) }\end{array}$ & $\begin{array}{l}\text { Portfolio Establishment } \\
\text { Optimal by Using Capital } \\
\text { Asset } \\
\text { Pricing Model on stocks that } \\
\text { are included in the LQ } 45 \\
\text { index on the Indonesia Stock } \\
\text { Exchange for the 2011-2015 } \\
\text { period }\end{array}$ & $\begin{array}{l}\text { Research results show } \\
\text { the selection of } 6 \text { stocks that make } \\
\text { up the optimal portfolio of } 13 \\
\text { research samples. The portfolios } \\
\text { included include UNVR with a } \\
\text { proportion of } 42.00 \% \text { of funds, } \\
\text { BBCA with a proportion of funds } \\
\text { of } 24.72 \% \text {, BBRI with a } \\
\text { proportion of funds of } 14.14 \% \text {, } \\
\text { LPKR with a proportion of funds } \\
\text { of } 11.34 \% \text {, CPIN with a } \\
\text { proportion of funds of } 7.68 \% \text {, and } \\
\text { GGRM with the proportion of } \\
\text { funds } \\
\text { by } 0.12 \% \text {. }\end{array}$ \\
\hline 3. & Fikry Yuliansyah (2018) & $\begin{array}{l}\text { Formation Comparison } \\
\text { Portfolio With } \\
\text { Using the Index Method } \\
\text { Sole And Capital Asset } \\
\text { Pricing Model (CAPM) } \\
\text { (Study on Jakarta Stock } \\
\text { Islamic Index (JII) Period } \\
\text { 2013-2016) }\end{array}$ & $\begin{array}{l}\text { Hasil penelitian menunjukkan } \\
\text { pembentukan portofolio } \\
\text { berdasarkan Capital Asset Pricing } \\
\text { Model (CAPM) menghasilkan } 10 \\
\text { saham perusahaan yang masuk ke } \\
\text { dalam portofolio efisien dari } 11 \\
\text { saham yang dijadikan sampel. } \\
\text { Saham perusahaan yang masuk ke }\end{array}$ \\
\hline
\end{tabular}




\begin{tabular}{|c|c|c|c|}
\hline & & & $\begin{array}{l}\text { dalam portofolio efisien yaitu } \\
\text { ADRO, ASII, ICBP, INDF, KLBF, } \\
\text { LSIP, TLKM, UNTR, UNVR, } \\
\text { WIKA dan pembentukan } \\
\text { portofolio optimal berdasarkan } \\
\text { Metode Indeks Tunggal dengan } \\
\text { menentukan saham yang masuk } \\
\text { dalam kandidat portofolio optimal } \\
\text { berdasarkan ERB bernilai positif } \\
\text { terpilihnya } 6 \text { saham dari } 11 \text { sampel } \\
\text { penelitian sebagai ADRO, TLKM, } \\
\text { LSIP, UNTR, UNVR dan ICBP. } \\
\text { Dari } 6 \text { saham kandidat portofolio } \\
\text { saham terpilih } 2 \text { saham yang } \\
\text { masuk portofolio optimal yaitu } \\
\text { saham ADRO dan TLKM. } \\
\text { Komposisi proporsi dana yang } \\
\text { terbentuk dengan menggunakan } \\
\text { indeks JII adalah ADRO dengan } \\
\text { proporsi dana sebesar } 21,54 \% \text { dan } \\
\text { TLKM dengan proporsi dana } \\
\text { sebesar 78,46\%. }\end{array}$ \\
\hline 4. & Sholikah (2017) & 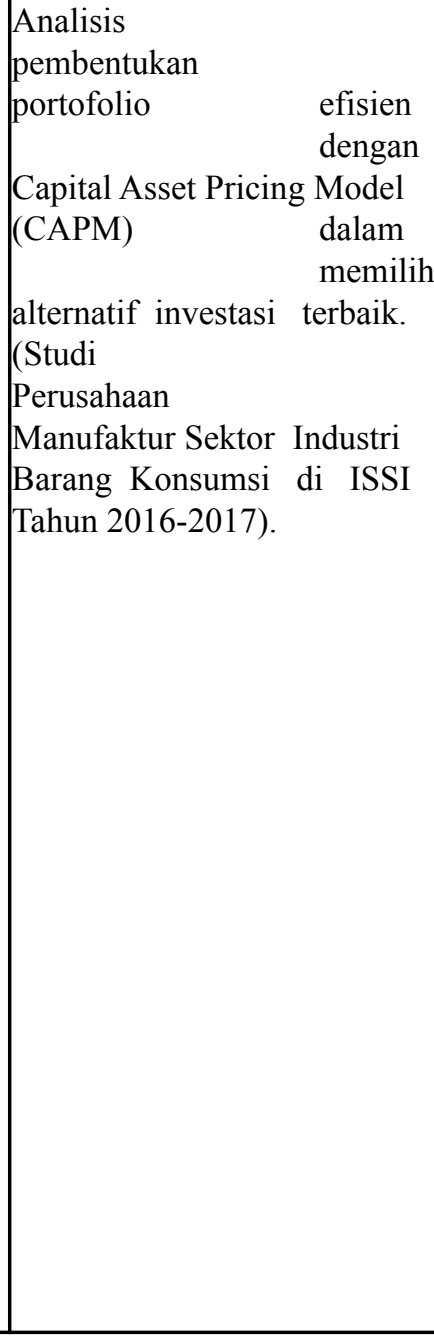 & $\begin{array}{l}\text { The results of the study show } \\
\text { the selection of } 10 \text { stocks } \\
\text { form an efficient portfolio of } \\
15 \text { research samples. From } 15 \\
\text { company used } 10 \\
\text { companies that include shares } \\
\text { undervalued or companies that } \\
\text { have a rate of return } \\
\text { individual share is greater than } \\
\text { rate of return that } \\
\text { expected (Ri) > E(Ri), and } 5 \\
\text { companies that include shares } \\
\text { overvalued. company that } \\
\text { classified as undervalued is PT. } \\
\text { Wilmar Cahaya Indonesia Tbk } \\
\text { (CEKA), Varia Power Laboratoria } \\
\text { Tbk (DVLA), Indofarma (Persero) } \\
\text { Tbk (INAF), Kimia Farma Tbk } \\
\text { (KAEF), Mandom Indonesia Tbk } \\
\text { (TCID), Martina Berto Tbk } \\
\text { (MBTO), Mustika Ratu Tbk } \\
\text { (MRAT), Unilever Indonesia Tbk } \\
\text { (UNVR), Kedawung Setia Industri } \\
\text { Tbk (KDSI) and PT. forever } \\
\text { Makmur Industri Tbk (LMPI), } \\
\text { for undervalued stocks } \\
\text { the decision taken is } \\
\text { buy the shares. Share } \\
\text { which includes overvalued } \\
\text { as many as } 5 \text { companies namely, } \\
\text { PT. } \\
\text { Akasha Wira International Tbk } \\
\end{array}$ \\
\hline
\end{tabular}




\begin{tabular}{|c|c|c|c|}
\hline & & & $\begin{array}{l}\text { (ADES), PT. Indofood CBP } \\
\text { Sukses Makmur Tbk (ICBP), } \\
\text { Sido Herbal and Pharmaceutical } \\
\text { Industry } \\
\text { Muncul Tbk (SIDO), Mustika } \\
\text { Ratu } \\
\text { Tbk (MRAT), and PT. Kedaung } \\
\text { Indah Tbk (KICI), for shares that } \\
\text { are overvalued, the decision taken } \\
\text { is to sell shares. }\end{array}$ \\
\hline 5 & Susanti (2016) & $\begin{array}{l}\text { Analisis Penggunaan Capital } \\
\text { Asset Pricing Model (CAPM) } \\
\text { Sebagai Dasar Pengambilan } \\
\text { Keputusan Investasi Saham } \\
\text { Pada Sub Sektor Perbankan di } \\
\text { Bursa Efek Indonesia (BEI) } \\
\text { periode } 2011 \text { - } 2014\end{array}$ & $\begin{array}{l}\text { The results of the study show } \\
\text { the selection of } 8 \text { stocks } \\
\text { form an efficient portfolio of } \\
21 \text { research samples. i.e. Bank } \\
\text { Central Asia Tbk (BBCA), Bank } \\
\text { Bukopin Tbk (BBKP), Bank } \\
\text { Negara Indonesia (Persero) Tbk } \\
\text { (BBNI), Bank Rakyat Indonesia } \\
\text { (Persero) Tbk (BBRI), Bank } \\
\text { Tabungan Negara (Persero) Tbk } \\
\text { (BBTN), Bank Jabar Banten } \\
\text { (BJBR), Bank Mandiri (Persero) } \\
\text { (BMRI) and Bank Woon Brothers } \\
\text { Indonesia 1906 Tbk (SDRA), } \\
\text { the decision taken is } \\
\text { take or buy and } \\
\text { There are 13 company shares } \\
\text { which is inefficient, namely the } \\
\text { Bank } \\
\text { MNC International Tbk (BABP), } \\
\text { Bank Danamon Indonesia Tbk } \\
\text { (BDMN), Bank Pundi Indonesia } \\
\text { Tbk (BEKS), Bank Bumi Artha } \\
\text { Tbk (BNBA), Bank CIMB Niaga } \\
\text { Tbk (BNGA), Bank Maybank } \\
\text { indonesia Tbk (BNII), Bank } \\
\text { Permata Indonesia (BNLI), Bank } \\
\text { Sinar Mas Tbk (BSIM), Bank } \\
\text { National Pension Savings Tbk } \\
\text { (BTPN), Bank Victoria } \\
\text { International Tbk (BVIC), Bank } \\
\text { Artha Graha Internasional Tbk } \\
\text { (INPC), Bank OCBC NISP Tbk } \\
\text { (NISP), and Bank Pan Indonesia } \\
\text { Tbk (PNBN) }\end{array}$ \\
\hline 6 & $\begin{array}{l}\text { Saputra, Wildan Deny, } \\
\text { et.al (2015) }\end{array}$ & $\begin{array}{l}\text { Penggunaan Metode Capital } \\
\text { Asset Pricing Model (CAPM) } \\
\text { Dalam Menentukan Saham } \\
\text { Efisien (Studi Pada Saham- }\end{array}$ & $\begin{array}{l}\text { The results of the study show that } \\
\text { from } \\
\text { Of the } 37 \text { company stocks } \\
\text { sampled, there are } 21 \text { company }\end{array}$ \\
\hline
\end{tabular}




\begin{tabular}{|l|l|l|}
\hline & $\begin{array}{l}\text { Saham Perusahaan Yang } \\
\text { Terdaftar Di Indeks Kompas } \\
100 \text { Periode 2010-2013) }\end{array}$ & $\begin{array}{l}\text { stocks that are included in the } \\
\text { efficient stock group, namely } \\
\text { AALI, AKRA, ASRI, BBCA, } \\
\text { BBKP, BBNI, BMRI, BWPT, } \\
\text { CPIN, GGRM, GJTL, INDF, } \\
\text { INTP, JSMR, KLBF, LPKR, } \\
\text { MNCN, PGAS, PTPP, SMGR, } \\
\text { UNVR and 16 shares of } \\
\text { companies that are included in the } \\
\text { group of inefficient shares, namely }\end{array}$ \\
ADRO, ANTM, ASII, BBRI, \\
BBTN, BDMN, INCO, INDY, \\
ITMG, LSIP, MEDC, PTBA, \\
SGRO, SMRA, TLKM, UNTR \\
\hline Panta Giri, Laxmi dan
\end{tabular}

The differences between this research and previous research are:

1. The research was conducted on stocks listed on the Investor Index 33 (INV33) and the Jakarta Islamic Index (JII).

2. The period used for research is the period $2016-2018$

\section{Result}

\subsection{Result}

Data analysis in this study was conducted by analyzing the formation of a stock portfolio and hypothesis testing analysis. Where the analysis of optimal portfolio formation using the Capital Asset Pricing Model (CAPM) method which then calculates the optimal portfolio return and risk. The description of the analysis of the results of this study begins with the formation of a stock portfolio, calculating the proportion of shares, calculating the return and risk of a stock portfolio and testing hypotheses.

\subsection{Individual Shares of Return (Ri)}

The rate of return on individual shares is the amount of real profit received by investors when investing in shares. The rate of return of shares is based on the monthly 
closing price of companies listed on the INV33 and JII Indexes for 2016-2018. Monthly closing price data (closing price) is taken from the website www.yahoofinance.com.

Table 1. Stock Return and Stock Variance List - INV33 . Index

\begin{tabular}{|r|l|l|c|c|}
\hline No. & Code & \multicolumn{1}{|c|}{ Name } & Ri & o' \\
\hline 1 & AALI & Astra Agro Lestari Tbk & $-0,003201$ & 0,007483 \\
\hline 2 & AKRA & AKR Corporindo Tbk & $-0,011242$ & 0,005767 \\
\hline 3 & AMRT & Sumber Alfaria Trijaya Tbk & 0,016257 & 0,005815 \\
\hline 4 & ASII & Astra International Tbk & 0,010304 & 0,002935 \\
\hline 5 & BBCA & Bank Central Asia Tbk & 0,019776 & 0,002047 \\
\hline 6 & BBNI & Bank Negara Indonesia (Persero) Tbk & 0,018720 & 0,005583 \\
\hline 7 & BBTN & Bank Tabungan Negara (Persero) Tbk & 0,024559 & 0,011336 \\
\hline 8 & BSDE & Bumi Serpong Damai Tbk & $-0,007053$ & 0,005807 \\
9 & CPIN & Charoen Pokphand Indonesia Tbk & 0,032992 & 0,008879 \\
\hline 10 & ICBP & Indofood CBP Sukses Makmur Tbk & 0,013498 & 0,002540 \\
\hline 11 & INDF & Indofood Sukses Makmur Tbk & 0,012413 & 0,004662 \\
\hline 12 & INTP & Indocement Tunggal Prakasa Tbk & 0,000606 & 0,011416 \\
\hline 13 & ITMG & Indo Tambangraya Megah Tbk & 0,047665 & 0,026418 \\
\hline 14 & JSMR & Jasa Marga (Persero) Tbk & $-0,003079$ & 0,004854 \\
\hline 15 & KLBF & Kalbe Farma Tbk & 0,005617 & 0,003353 \\
\hline 16 & PGAS & Perusahaan Gas Negara (Persero) Tbk & 0,001997 & 0,020568 \\
\hline 17 & PTPP & PP (Persero) Tbk & $-0,013321$ & 0,013295 \\
\hline 18 & PWON & Pakuwon Jati Tbk & 0,009388 & 0,006485 \\
\hline 19 & SMGR & Semen Indonesia (Persero) Tbk & 0,004604 & 0,009314 \\
\hline 20 & SMRA & Summarecon Agung Tbk & $-0,013724$ & 0,014355 \\
\hline 21 & TBIG & Tower Bersama Infrastructure Tbk & $-0,010102$ & 0,006716 \\
\hline 22 & TLKM & Telekomunikasi Indonesia (Persero) & 0,006967 & 0,003329 \\
\hline 23 & UNVR & Unilever Indonesia Tbk & 0,007319 & 0,003391 \\
\hline 24 & UNTR & United Tractor Tbk & 0,016649 & 0,006647 \\
\hline & & & \\
\hline
\end{tabular}

Based on table 1. shows the stock return (Ri) and stock variance $(\sigma i)$ during the 2016-2018 period from the INV33 Index. There are 17 stocks that have a positive average rate of return $[(\mathrm{Ri})>0]$ and 7 stocks that have a negative average rate of return $[(\mathrm{Ri})<0]$. The highest average rate of return (Ri) of the 24 stocks was ITMG at 0.047665 while the lowest value was INTP at 0.000606 . Meanwhile, the highest stock variance ( $\sigma i)$ was ITMG at 0.026418 while the lowest value was BBCA at 0.002047 . 
Table 2. List of Stock Returns and Stock Variances - JII Index

\begin{tabular}{|l|l|l|r|c|}
\hline No. & $\begin{array}{c}\text { Kode } \\
\text { Saham }\end{array}$ & \multicolumn{1}{|c|}{ Nama Emiten } & Ri & б.2 \\
\hline 1 & ADRO & Adaro Energy Tbk. & 0,029868 & 0,011835 \\
\hline 2 & AKRA & AKR Corporindo Tbk & $-0,011242$ & 0,005767 \\
\hline 3 & ASII & Astra International Tbk & 0,010304 & 0,002935 \\
\hline 4 & BSDE & Bumi Serpong Damai Tbk & $-0,007053$ & 0,005807 \\
\hline 5 & ICBP & Indofood CBP Sukses Makmur Tbk & 0,013498 & 0,002540 \\
\hline 6 & INCO & Vale Indonesia Tbk & 0,030180 & 0,022939 \\
\hline 7 & INDF & Indofood Sukses Makmur Tbk & 0,012413 & 0,004662 \\
\hline 8 & KLBF & Kalbe Farma Tbk & 0,005617 & 0,003353 \\
\hline 9 & LPPF & Matahari Department Store Tbk. & $-0,025773$ & 0,010639 \\
10 & PGAS & Perusahaan Gas Negara (Persero) Tbk & 0,001997 & 0,020568 \\
\hline 11 & PTPP & PP (Persero) Tbk & $-0,013321$ & 0,013295 \\
\hline 12 & SMGR & Semen Indonesia (Persero) Tbk & 0,004604 & 0,009314 \\
\hline 13 & SMRA & Summarecon Agung Tbk & $-0,013724$ & 0,014355 \\
\hline 14 & TLKM & Telekomunikasi Indonesia (Persero) & & \\
\hline 15 & UNTR & United Tractor Tbk & 0,006967 & 0,003329 \\
\hline 16 & UNVR & Unilever Indonesia Tbk & 0,016649 & 0,006647 \\
\hline 17 & WIKA & Wijaya Karya (Persero) Tbk. & $-0,003236$ & 0,016234 \\
\hline
\end{tabular}

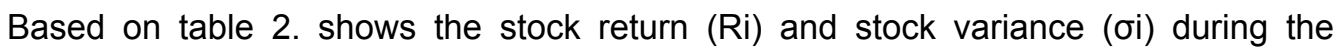
2016-2018 period from the $\mathrm{JII}$ Index. There are 17 stocks that have a positive average rate of return $[(\mathrm{Ri})>0]$ and 7 stocks that have a negative average rate of return $[(\mathrm{Ri})<0]$. The highest average rate of return (Ri) of the 17 stocks was INCO at 0.030180 while the lowest value was PGAS at 0.001997 . Meanwhile, the highest stock variance (бi) was INCO at 0.022939 while the lowest value was ICBP at 0.002540 .

Table 3. List of Stock Returns and Stock Variances - JII Index

\begin{tabular}{|r|l|l|c|c|}
\hline No. & Code & \multicolumn{1}{|c|}{ Name } & E(Ri) & o. \\
\hline 1 & AALI & Astra Agro Lestari Tbk & $-0,003201$ & 0,007483 \\
\hline 2 & AKRA & AKR Corporindo Tbk & $-0,011242$ & 0,005767 \\
\hline 3 & BSDE & Bumi Serpong Damai Tbk & $-0,007053$ & 0,005807 \\
\hline 4 & JSMR & Jasa Marga (Persero) Tbk & $-0,003079$ & 0,004854 \\
\hline 5 & PTPP & PP (Persero) Tbk & $-0,013321$ & 0,013295 \\
\hline 6 & SMRA & Summarecon Agung Tbk & $-0,013724$ & 0,014355 \\
\hline 7 & TBIG & Tower Bersama Infrastructure Tbk & $-0,010102$ & 0,006716 \\
\hline
\end{tabular}

Based on table 3 , it shows that there are 7 stocks that have an average negative rate of return $[(\mathrm{Ri})<0]$ from the INV33 Index. Stocks with an average negative rate of return are not included in the candidate stock portfolio.

\subsection{Discussion of Research Results}


A. Comparison of the optimal stock portfolio composition for stocks included in the Investor33 Index and JII on the Indonesia Stock Exchange in 2016-2018 using the Capital Asset Pricing Model (CAPM) model

In the formation of efficient stocks included in INV33 for the January 2016-December 2018 period, 17 samples from 33 stocks included in the INV33 index were used. Meanwhile, in the formation of efficient stocks that are included in the $\mathrm{JII}$ for the January 2016-December 2018 period, 11 samples of 30 stocks included in the JII index are used. Stocks included in the research sample are stocks that are included in the INV33 and $\mathrm{JII}$ indices continuously during the study period. The data needed in the study, apart from the company stock sample, is also the closing price, JCI, INV33, JII and BI Rate.

For the selection of which stocks are included as efficient and inefficient stocks using the Capital Asset Pricing Model (CAPM) approach and are included in the optimal portfolio formation candidates. If the stock return $(\mathrm{Ri})$ is greater than the expected return $[(\mathrm{Ri})>(\mathrm{E}(\mathrm{Ri})]$, it is categorized as an efficient stock, while if the stock return is less than the expected return $[(\mathrm{Ri})<(\mathrm{E}(\mathrm{Ri})]$, it is categorized as an inefficient stock.

Table 4. List of Stock Returns and Stock Variances - JII Index

\begin{tabular}{|c|c|c|c|c|c|c|c|}
\hline \multicolumn{4}{|c|}{ Indeks INV33 } & \multicolumn{4}{|c|}{ Indeks JII } \\
\hline No. & Code & $\mathbf{R i}$ & $E(R i)$ & No. & Code & $\mathbf{R} \mathbf{i}$ & $E(R i)$ \\
\hline 1 & BBCA & 0,01978 & 0,01000 & 1 & ADRO & 0,02987 & 0,01383 \\
\hline 2 & BBNI & 0,01872 & 0,01564 & 2 & ICBP & 0,01350 & 0,00772 \\
\hline 3 & BBTN & 0,02456 & 0,01722 & 3 & INCO & 0,03018 & 0,00923 \\
\hline 4 & CPIN & 0,03299 & 0,00938 & 4 & INDF & 0,01241 & 0,01073 \\
\hline 5 & ICBP & 0,01350 & 0,00772 & 5 & TLKM & 0,00697 & 0,00419 \\
\hline 6 & INDF & 0,01241 & 0,01073 & 6 & UNTR & 0,01665 & 0,00855 \\
\hline 7 & ITMG & 0,04766 & 0,01621 & & & & \\
\hline 8 & TLKM & 0,00697 & 0,00419 & & & & \\
\hline 9 & UNTR & 0,01665 & 0,00855 & & & & \\
\hline
\end{tabular}

Based on table 5.34 shows the results of efficient stock portfolio calculations based on the INV33 and JII indexes. The calculation results from the 17 sample stocks there are 9 efficient stocks that have Ri>E(Ri) based on the INV33 index and the calculation results from the 11 sample stocks there are 6 efficient stocks that have $\mathrm{Ri}>\mathrm{E}(\mathrm{Ri})$ based on the $\mathrm{JII}$ index.

After getting an efficient stock portfolio, the next step is to determine the optimal stock portfolio. In determining the optimal portfolio are efficient stocks that have ERB $\geq \mathrm{Ci}$ from the calculation results by comparing ERB and $\mathrm{Ci}$. The $\mathrm{Ci}$ calculation is used to determine the Cut Off Point $\left(\mathrm{C}^{*}\right)$ value which is carried out by observing the maximum $\mathrm{Ci}$ value from a series of $\mathrm{Ci}$ values. The value of $\mathrm{C}^{*}$ is used to determine which stock limit points are included as optimal portfolio candidates. The securities that make up the optimal portfolio are those that have an ERB value greater than or equal to the ERB value at point $C^{*}$. The securities that have a smaller ERB value with the ERB value at point $C^{*}$ is not included in the formation of the optimal portfolio.

\section{Conclusion}

Based on the results and discussion of the Capital Asset Pricing Model research 
method on stocks included in the INV33 Index and the JII Index, the following conclusions can be drawn:

1. There are 7 stocks that meet the criteria for forming an optimal stock portfolio using the INV33 Index, namely CPIN (Charoen Pokphand Indonesia Tbk), ITMG (Indo Tambangraya Megah Tbk), BBCA (Bank Central Asia Tbk), UNTR (United Tractor Tbk), (TLKM) Telekomunikasi Indonesia (Persero) Tbk, ICBP (Indofood CBP Sukses Makmur Tbk), BBTN (State Savings Bank Persero Tbk). There are 6 stocks that meet the criteria for forming an optimal stock portfolio using the JII Index, namely ADRO (Adaro Energy Tbk), ICBP (Indofood CBP Sukses Makmur Tbk), INCO (Vale Indonesia Tbk), INDF (Indofood Sukses Makmur Tbk), TLKM (Telekomunikasi Indonesia Persero Tbk), UNTR (United Tractor Tbk).

2. The proportion of funds from the optimal portfolio of shares using the INV33 Index is the highest proportion is BBCA and the lowest proportion is BBTN, while the proportion of funds from the optimal portfolio of shares using the $\mathrm{JII}$ Index is the highest proportion is ICBP and the lowest proportion is INDF. There are 3 stocks that are included in the optimal portfolio in both the INV33 index and the JII index, namely UNTR, TLKM and ICBP. The banking sector stocks based on the INV33 Index have a majority proportion consisting of BBCA and BBTN while in the $\mathrm{JII}$ Index there is no banking sector because they are not included in the criteria of Islamic Sharia

3. The amount of return from the optimal stock portfolio using the INV33 Index is higher than the $\mathrm{JII}$ Index and the risk from the optimal stock portfolio using the INV33 Index is lower than the JII Index.

\section{Suggestion}

After analyzing and discussing the formation of an optimal portfolio using the Capital Asset Pricing Model method on stocks that are included in the INV33 Index and JII Index on the Indonesia Stock Exchange for the period January 2016 - December 2018, the suggestions from this research are as follows:

1. For investors, the results of this study can be used as a consideration in making decisions and stock investment strategies.

2. For academics, this research can be a reference for the development 
of financial management science regarding optimal portfolio analysis with CAPM.

3. For further research, you can continue this research on optimal portfolio formation using other stock indexes such as Kompas 100 and using weekly stock closing data or with a longer research period

\section{References}

[1] Hunjra, A. I., Alawi, S. M., Colombage, S., Sahito, U., \& Hanif, M. (2020). Portfolio Construction by Using Different Risk Models: A Comparison among Diverse Economic Scenarios. Risks, 8(4), 126.

[2] Moriarty, E., Phillips, S., \& Tosini, P. (1981). A comparison of options and futures in the management of portfolio risk. Financial Analysts Journal, 37(1), 61-67.

[3] Ferruz, L., Gómez-Bezares, F., \& Vargas, M. (2010). Portfolio theory, CAPM and performance measures. In Handbook of Quantitative Finance and Risk Management (pp. 267-281). Springer, Boston, MA.

[4] Heikal, J., Rialialie, V., Rivelino, D., \& Supriyono, I. A. (2022). Hybrid Model Of Structural Equation Modeling Pls And Rfm (Recency, Frequency And Monetary) Model To Improve Bank Average Balance. Aptisi Transactions on Technopreneurship (ATT), 4(1), 1-8.

[5] Lumme, M. (2021). Data-driven portfolio analysis for office buildings' energy efficiency retrofit projects.

[6] Woodroof, E. A., \& Thumann, A. (2021). How to Finance Energy Management Projects: Solving the" lack of Capital Problem". CRC Press.

[7] Gonçalves, T., \& Gaio, C. (2021). The role of management accounting systems in global value strategies. Journal of Business Research, 124, 603-609.

[8] Purnama, S., Bangun, C. S., \& Faaroek, S. A. (2021). The Effect of Transaction Experience Using Digital Wallets on User Satisfaction in Millennial Generation. Aptisi Transactions on Management (ATM), 5(2), 161-168.

[9] Rosanna, N., Hery, H., \& Widjaja, A. E. (2021). Designing Information Systems for Transaction and Production Data Management A\&N convection. IAIC Transactions on Sustainable Digital Innovation (ITSDI), 2(2), 121-130.

[10] Chhimwal, B., \& Bapat, V. (2021). Comparative study of momentum and contrarian behavior of different investors: Evidence from the Indian Market. Asia-Pacific Financial Markets, 28(1), 19-53.

[11] Dreicer, T. (2021). Design Portfolio for The Tri-Cities Homestead 2.0: A Second Look at a DOE Solar Decathlon Net Zero Home Design.

[12] Amsyar, I., Christopher, E., Dithi, A., Khan, A. N., \& Maulana, S. (2020). The Challenge of Cryptocurrency in the Era of the Digital Revolution: A Review of Systematic Literature. Aptisi Transactions on Technopreneurship (ATT), 2(2), 153-159.

[13] Hamada, R. S. (1969). Portfolio analysis, market equilibrium and corporation finance. The Journal of Finance, 24(1), 13-31.

[14] Purbasari, A., Maryono, G. P., Mulyanto, F., \& Gusdya, W. (2021). Utilization of Google My Business as a Tourism Promotion Media Using Local Search Engine Optimization. IAIC Transactions on Sustainable Digital Innovation (ITSDI), 2(2), 169-178.

[15] LUBIS, A., DALIMUNTHE, R., ABSAH, Y., \& FAWZEEA, B. K. (2021). The Effect of Corporate Communication and Service Quality on Customer Loyalty and Satisfaction in 
Sharia Banking. The Journal of Asian Finance, Economics, and Business, 8(3), 1267-1274.

[16] Heikal, J., Rialialie, V., Rivelino, D., \& Supriyono, I. A. (2022). Hybrid Model Of Structural Equation Modeling Pls And Rfm (Recency, Frequency And Monetary) Model To Improve Bank Average Balance. Aptisi Transactions on Technopreneurship (ATT), 4(1), 1-8.

[17] Santosa, A. B., Nusantara, A., \& Nawatmi, S. (2019, July). The Portofolio Model of Exchange Rate Determination: The case of Rupiah exchange rate. In International Conference on Banking, Accounting, Management, and Economics (ICOBAME 2018) (pp. 140-143). Atlantis Press.

[18] Marginean, S. (2015). Economic globalization: From microeconomic foundation to national determinants. Procedia Economics and Finance, 27, 731-735.

[19] Mahayani, N. P. M., \& Suarjaya, A. G. (2019). PENENTUAN PORTOFOLIO OPTIMAL BERDASARKAN MODEL MARKOWITZ P ADA PERUSAHAAN INFRASTRUKTUR DI BURSA EFEK INDONESIA. E-Jurnal Manajemen, 8(5), 2057-3085.

[20] Risnawati, Y. (2009). Analisis investasi dan penentuan portofolio saham optimal di Bursa Efek Indonesia (studi komparatif penggunaan model indeks tunggal dan model random pada saham LQ-45). 